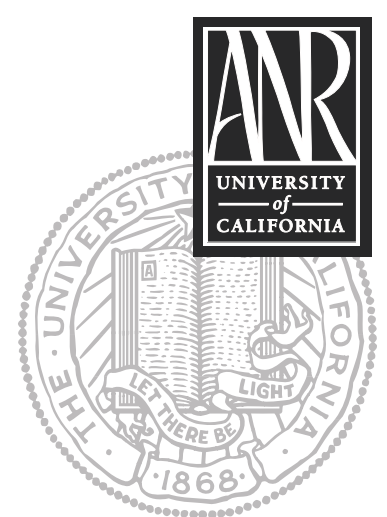

UNIVERSITY OF CALIFORNIA

Division of Agriculture and Natural Resources http://anrcatalog.ucdavis.edu

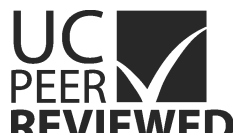

\title{
State and Federal Approach to Control of Nonpoint Sources of Pollution
}

J. M. GERSTEIN, UC Berkeley Center for Forestry; D. J. LEWIS, UCCE Watershed Advisor, Marin, Mendocino, and Sonoma Counties; K. RODRIGUES, UCCE North Coast and Mountain Region Director; J. M. HARPER, UCCE Livestock and Natural Resources Advisor, Mendocino County; and J. KABASHIMA, UCCE Environmental Horticulture Advisor, Orange County The successful control of nonpoint source (NPS) pollution or polluted runoff relies on a combination of outreach, education, cooperation, and technical assistance for agricultural and timber landowners. The primary goal of this publication is to clarify the responsibilities of agriculturists and natural resource managers with regard to water quality regulation compliance in California. This is one component of an outreach program being designed jointly by University of California Cooperative Extension (UCCE) and staff from the North Coast Regional Water Quality Control Board. As such, it represents a commitment by both agencies to work together to assist landowners in controlling NPS pollution and improving water quality, statewide.

\section{REGULATORY STATUS}

On May 20, 2004, the California State Water Resources Control Board (SWRCB) adopted a new policy regulating NPS pollution. This policy affects landowners as well as operators throughout the state who are engaged in agricultural production, timber harvest operations, and other potential sources of NPS pollution. Known as the Policy for Implementation and Enforcement of the Nonpoint Source (NPS) Pollution Control Program (or, more briefly, the NPS Implementation and Enforcement Policy), this policy was required by Senate Bill 390, enacted in 1999. This publication gives an update on NPS pollution regulation in California, explaining the current requirements imposed by the SWRCB and Regional Water Quality Control Boards (RWQCBs) on agricultural producers and landowners as potential dischargers of NPS pollution.

\section{Shedding Tiers: California Legislature and State Water Resources Control Board Reaffirm Authority in Porter-Cologne Act}

The three-tiered approach to nonpoint source pollution control was officially set aside on May 20, 2004, when the California State Water Resources Control Board (SWRCB) approved the Policy for the Implementation and Enforcement of the Nonpoint Source (NPS) Pollution Control Program.

In 1999, the California Legislature passed Senate Bill 390, which rescinded long-standing "waivers" for agriculture and forestry, eliminated the tiered approach, and directed the SWRCB to develop this new policy. The policy reaffirmed the authority of both the SWRCB and the Regional Water Quality Control Boards (RWQCBs) to regulate all discharges of waste, which had been in effect since the passing of the Porter-Cologne Act in 1969. This includes the regulation of NPS pollution from agricultural and timber lands. In clarifying their authority, the policy also requires that RWQCBs actively regulate ongoing and potential NPS discharges and implement an NPS pollution control program.

\section{WHAT ARE NONPOINT SOURCES OF POLLUTION?}

Federal water quality regulations differentiate nonpoint sources from point sources of pollution. Point sources include pipes or ditches coming from factories, water treatment plants, or other facilities or sites with a distinct, identifiable source. Nonpoint sources enter waterways as runoff from diffuse, distributed sources across the landscape. Since much of California's land is in forests, rangeland, and agriculture, associated land use activities are considered potential sources for NPS pollution in addition to urban landscapes.

California's Porter-Cologne Water Quality Control Act does not differentiate between the regulation of point source pollution and NPS pol- 
lution. Instead, it states that any activity or factor that affects water quality is subject to regulation. This means that the law covers not only materials that enter the water column directly, like manure or sediment (known as waste discharges or pollutants), but also processes that affect water quality. For example, decreases in flow or reductions of riparian shade can cause an increase in water temperature, a form of pollution that is subject to regulation.

The most common pollutants and pollution that may originate from agriculture and timber lands are sediment, elevated water temperatures, nutrients, pathogens, pesticides, heavy metals, and oil and grease. Even though many of these constituents occur naturally in most water bodies, excessive levels of these constituents can impair or eliminate the availability of beneficial uses in these water bodies. For example, increased turbidity can impair domestic water supplies and elevated stream temperatures can decrease fish survival.

Although state and federal laws regarding the control of NPS pollution have been in existence since the early 1970s, water quality enforcement initially focused on point sources. More recently the focus has shifted to NPS pollution. Efforts to control NPS pollution are likely to continue to increase for the foreseeable future. According to the US Environmental Protection Agency(US EPA 1996),

Today, nonpoint source (NPS) pollution remains the Nation's largest source of water quality problems. It's the main reason that approximately 40 percent of our surveyed rivers, lakes, and estuaries are not clean enough to meet basic uses such as fishing or swimming.

Here in California, there are 685 water bodies on California's 2002 Clean Water Act Section 303(d) List of Water Quality Limited Segments (SWRCB, 2002). When combined with the number of pollutants by which a water body is impaired, there are 1,883 water body-pollutant combinations on the list. Regulations and policies for controlling NPS pollution are being implemented across the state to address these impacted waters.

\section{FEDERAL LAW REGARDING NPS POLLUTION}

The United States Clean Water Act and the Coastal Zone Management Act, both enacted in the 1970s, are the primary federal statutes that mandate states to control water quality. Funding for the individual State to administer the required planning and regulatory programs is provided through the U.S. EPA and requires that the State submit plans for control of NPS pollution that meet criteria established by federal law. The State must also provide assurances that it has the necessary regulatory authority to implement the plans.

\section{CALIFORNIA AUTHORITY FOR REGULATING NPS POLLUTION}

Within California, the main statute that gives State and Regional Boards the authority to control water quality is the Porter-Cologne Act, which was initially adopted in 1969. The underlying principle of the Porter-Cologne Act is that "all discharges of waste into the waters of the state are privileges, not rights." Although formal policy for the regulation of NPS pollution is a relatively recent development in California, the authority to create and enforce such a policy has always existed within the PorterCologne Act. Now that the state is focusing more energy on controlling NPS pollution, new policies and plans have been developed at the state level and regional boards are developing plans that conform to those policies.

In January of 2000, the SWRCB approved a plan for NPS pollution regulation that includes two volumes: 
Volume I: Nonpoint Source Program Strategy and Implementation Plan (1998-2013 NPS Program Plan)

Volume II: California Management Measures for Polluted Runoff (January 2000)

This same plan was also reviewed and approved by the EPA.

The January 2000 plan described what was known as the "Three-Tiered Approach" for controlling NPS pollution. In May of 2004, this approach was superceded when the SWRCB adopted the Policy for the Implementation and Enforcement of the Nonpoint Source Pollution Control Program, or NPS Implementation and Enforcement Policy. This policy clarified and made more specific the long-existing authority that rested with the SWRCB and RWQCBs to control all discharges of waste, including NPS pollution.

\section{WHO'S IN CHARGE?}

Two California agencies share responsibility for developing and implementing the NPS pollution control policies: the SWRCB and the nine RWQCBs. The SWRCB adopts policy for water quality control, statewide water quality control plans, and regulations that are binding on the nine RWQCBs. The SWRCB also hears appeals from RWQCB actions. The RWQCBs adopt regional water quality control plans, issue permits to implement basin- or region-wide water quality requirements, and, when necessary, take enforcement actions. Because of geographic differences between the regions, individual RWQCBs may develop different approaches to NPS pollution control implementation, but these approaches all must be consistent with the law and with SWRCB policy.

The NPS pollution Implementation and Enforcement Policy reaffirms the RWQCBs' use of the three existing permitting authorities contained in the PorterCologne Act for control of NPS pollution discharge. These permitting authorities are

- Waste Discharge Requirements (WDR) - either individual or general permits adopted by RWQCBs, with specific criteria, conditions, and limitations that describe how waste discharge from specific land management can be allowed. WDRs require submittal of a report of waste discharge, annual fees, and approval by the respective RWQCB.

- Waivers of WDR - either individual or categorical permits for land management activities that RWQCBs have determined, after a formal hearing, to be consistent with state law. Waivers are conditional, with specific directions and requirements intended to reduce NPS discharge and impacts from permitted activities. Activities waived by RWQCBs may be exempt from filing a report of waste discharge and from annual fee requirements.

- Basin Plan Prohibitions - restrictions on pollutant discharges contained within a RWQCB's Basin Plan rather than in permits issued to individuals or groups. This regulatory tool is used when discharges occur without either of the first two types of permit and provide a mechanism for immediate enforcement action to control a discharge.

In addition to these administrative permitting authorities, the NPS pollution Implementation and Enforcement Policy references enforcement options available to the SWRCB and RWQCBs. These enforcement options are authorized by the PorterCologne Act. Possible enforcement actions include (but are not limited to) Notice of Violation (NOV), Notice to Comply (NTC), Cleanup and Abatement Orders (CAOs), Cease and Desist Orders (CDOs), and fines in the form of Administrative Civil Liabilities (ACL). 
It is worth noting that in urban settings, effects on water quality from agricultural operators can be regulated through the National Pollutant Discharge Elimination System (NPDES) storm water program and Storm Water Phase II Final Rule (US EPA 2000a). More specifically, small-scale growers and nurseries in an urban area can be regulated by a municipal separate storm sewer system (MS4) storm water management plan (US EPA 2000b). In this case, a county or municipality is the permittee and works with growers through an inspection process to ensure compliance.

The NPS pollution Implementation and Enforcement Policy also requires that dischargers develop and implement NPS pollution control programs that meet SWRCB and RWQCB water quality requirements. The policy identifies the following five key elements:

- Element 1 - Explanation of the purpose of the NPS pollution program and how it will meet water quality requirements.

- Element 2 - Description of the specific best management practices (commonly known as BMPs) that will be used to meet water quality goals.

- Element 3 - A timeline for implementing the program.

- Element 4-A monitoring program to verify that management practices were implemented and that they were effective in meeting water quality requirements.

- Element 5 - Clear explanation of consequences of not meeting the stated purpose of the program. Developing this element is primarily the responsibility of the RWQCB.

\section{WHAT DOES THIS MEAN ON THE GROUND?}

The NPS Implementation and Enforcement Policy requires that the SWRCB and RWQCBs use the permitting and enforcement authorities delegated to them by the Porter-Cologne Act to regulate NPS pollution and to enforce their regulations. Within the limits of available staff time and resources, RWQCBs are now required to actively engage in NPS pollution control through the now-clarified and specific authorities that have been in existence since the passing of the Porter-Cologne Act in 1969. Growers and producers, in turn, are responsible for choosing management practices that effectively control nonpoint pollution sources on their property.

Admittedly, available staff time and resources for SWRCB and RWQCBs are limited, when compared to the vast area and number of landowners that may be considered "dischargers." Thus, successful control of NPS pollution must rely largely on outreach, education, and technical assistance to landowners, in addition to the regulatory options. In some instances, this lack of resources has served as the grounds for successful lawsuits against regulatory agencies, arguing that they have failed to comply with state and federal regulations. These court decisions have led to cease and desist orders, consent decrees, and accelerated timelines that dictate how both the regulatory agencies and dischargers implement NPS pollution regulations. Growers and producers can avoid this kind of litigated regulation by pursuing a proactive water quality management program.

Since water quality regulation is implemented through the nine independent RWQCBs, the specifics of what will change or happen on the ground may be different for different regions and land uses. Future publications in this series will provide guidance on RWQCBs' specific efforts to control NPS pollution. In addition, you may request information from individual RWQCBs about their own specific programs and policies.

As RWQCBs formalize their application of the state NPS pollution policy, land managers may need to seek guidance in finding the answers to the following questions: 
1. Do my land management activities have the potential to discharge waste (for example, sediment, nutrients, pathogens or pesticides) or cause a condition of pollution (for example, by raising water temperature) to waters of the state?

2. If so, under which administrative authority (WDRs, waivers, or prohibitions) will my activity be regulated? In some cases, you may have a choice of when to conduct your land management activities in a way that complies with either a conditional waiver or a general WDR. The final decision, however, is up to the RWQCB.

3. If I have an existing water quality management plan, can it be revised to meet the needs of an NPS Pollution Control Program? It is possible that Farm and Ranch Water Quality Planning and other conservation efforts, with groups like Resource Conservation Districts, can serve as a starting point from which you can develop additional program elements to meet the NPS Implementation and Enforcement Policy's "five key elements" requirements.

Our goal in providing the questions and information in this publication is to clarify California water quality regulations for you, along with the responsibilities and roles that agricultural and timber landowners have in reducing discharges of waste and pollution to waters of the state. In the end, a potential discharger will need to identify human-caused sources of sediment, nutrients, temperature, pathogens, and pesticides on the property he or she manages. A program to address those sources within a specified time frame will also have to be developed, along with some way to monitor results. While there certainly are details to be worked out, it need not be any more complicated than that. Additional information and guidance are available through RWQCB offices and through local University of California Cooperative Extension, USDA Natural Resources Conservation Service, and Resource Conservation District offices.

\section{SOURCES OF ADDITIONAL INFORMATION}

Jones, A., T. Harter, M. Bianchi, and J. Harper. 2003. Water pollution control legislation: Farm water quality planning Reference Sheet 8.1. Oakland: University of California, Division of Agriculture and Natural Resources. Publication 8088. http://anrcatalog.ucdavis.edu/pdf/8088.pdf.

State Water Resources Control Board (SWRCB). 2000. Nonpoint source program strategy and implementation plan, 1998-2013 (PROSIP). Sacramento: California Environmental Protection Agency.

—. 2002. Clean Water Act, Section 303(d): List of water quality limited segments. Sacramento: California Environmental Protection Agency.

- 2004. Policy for implementation and enforcement of the Nonpoint Source Pollution Control Program. Sacramento: California Environmental Protection Agency.

United States Environmental Protection Agency (US EPA). 1996. Nonpoint source pollution: The nation's largest water quality problem. Pointer No. 1. EPA841F-96-004A. http://www.epa.gov/owow/nps//facts/pointl.htm.

. 2000a. Storm water phase II final rule: An overview. EPA-F-00-001. Fact Sheet 1.0. http://www.epa.gov/npdes/pubs/factl-0.pdf.

. 2000b. Small MS4 storm water program overview. EPA 833-F-00-002.

Fact Sheet 2.0. 


\section{WEB SITE RESOURCES}

\section{Federal Level}

United States Environmental Protection Agency, Office of Water, Nonpoint Source Web site, http://www.epa.gov/owow/nps/

United States Environmental Protection Agency, Storm Water Phase II Final Rule, Fact Sheet series, http://cfpub.epa.gov/npdes/stormwater/swfinal.cfm

\section{State Level}

NPS Implementation Policy http://www.swrcb.ca.gov/nps/docs/oalfinalcopy052604.doc

NPS Plan, Volume I

http://www.waterboards.ca.gov/nps/docs/planvoll.doc

NPS Plan, Volume II

http://www.swrcb.ca.gov/nps/cammpr.html

State Water Resources Control Board, Nonpoint Source Pollution Control Program Web site: http://www.swrcb.ca.gov/nps/protecting.html

\section{OTHER POINTS OF CONTACT FOR INFORMATION ON NPS PROGRAM PLAN}

If you would like a CD containing the NPS Program Plan sent to you, please leave your name and mailing address with Kelly Maurie at (916) 327-9530 or send her an e-mail at kmaurie@waterboards.ca.gov. For any problems associated with downloading the NPS Program Plan, please contact Mary Tappel at (916) 341-5491 or send her an e-mail at mtappel@waterboards.ca.gov.

If you have any questions concerning the NPS Program Plan, please send them to Steve Fagundes, Chief of NPS Program Plan Implementation Unit at the State Water Resources Control Board: 1001 "I" Street, 15th Floor, Sacramento, CA 95814. You may also contact him at (916) 341-5487 or send him an e-mail at sfagundes@waterboards.ca.gov.

\section{ACKN OWLEDGMENTS}

In addition to our collaboration with North Coast Regional Water Quality Control Board staff, review and input from Katherine Domeny and Steve Fagundes was very helpful in developing this publication. This publication was written with support from the USDA Renewable Resources Extension Act.

\section{FOR MORE INFORMATION}

You'll find related information in these titles and in other publications, slide sets, CD-ROMs, and videos from UC ANR:

Developing a Nonpoint Source Pollution Evaluation Program, Publication 8087

Nonpoint Sources of Pollution in Irrigated Agriculture, Publication 8055

The Farm Water Quality Plan, Publication 9002

To order these products, visit our online catalog at http://anrcatalog.ucdavis.edu. You can also place orders by mail, phone, or FAX, or request a printed catalog of publications, slide sets, CD-ROMs, and videos from 


\author{
University of California \\ Agriculture and Natural Resources \\ Communication Services \\ 6701 San Pablo Avenue, 2nd Floor \\ Oakland, California 94608-1239 \\ Telephone: (800) 994-8849 or (510) 642-2431 \\ FAX: (510) 643-5470 \\ E-mail inquiries: danrcs@ucdavis.edu
}

An electronic version of this publication is available on the ANR Communication Services Web site at http://anrcatalog.ucdavis.edu.

Publication 8203

ISBN-13: 978-1-60107-394-5

ISBN-10: 1-60107-394-1

This publication has been anonymously peer reviewed for technical accuracy by University of California scientists and other qualified professionals. This review process was managed by the ANR Associate Editor for Land, Air, and Water Sciences.

(C)2006 by the Regents of the University of California

Division of Agriculture and Natural Resources.

All rights reserved.

The University of California prohibits discrimination or harassment of any person on the basis of race, color, national origin, religion, sex, gender identity, pregnancy (including childbirth, and medical conditions related to pregnancy or childbirth), physical or mental disability, medical condition (cancer-related or genetic characteristics), ancestry, marital status, age, sexual orientation, citizenship, or status as a covered veteran (covered veterans are special disabled veterans, recently separated veterans, Vietnam era veterans, or any other veterans who served on active duty during a war or in a campaign or expedition for which a campaign badge has been authorized) in any of its programs or activities.

University policy is intended to be consistent with the provisions of applicable State and Federal laws.

Inquiries regarding the University's nondiscrimination policies may be directed to the Affirmative Action/Staff Personnel Services Director, University of California, Agriculture and Natural Resources, 1111 Franklin Street, $6^{\text {th }}$ Floor, Oakland, CA 94607, (510) 987-0096. For information about obtaining this publication, call (800) 994-8849. For downloading information, call (530) 297-4445.

pr-11/06-WJC/CAM 